\title{
Dietary influences on lutein pigments and carcass fat quality in wethers of different maturity types
}

\author{
E.C. Webb*, N.H. Casey \\ Department of Animal and Wildlife Sciences, Faculty of Biological and Agricultural Sciences, \\ University of Pretoria, Pretoria, 0002, Republic of South Africa \\ M.J.C. Bosman \\ Department of Nutrition and Family Ecology, Potchefstroom University for CHE, Potchefstroom, \\ Republic of South Africa
}

Received (revised) 29 January 1999; accepted 29 January 1999

\begin{abstract}
The aim of this research was to study the effect of high-maize diets and pelleting on the accumulation of lutein pigments and appearance of the subcutaneous fat in Dorper and SA Mutton Merino wethers. High and medium energy maize diets were fed to Dorper and SA Mutton Merino wethers from an initial live weight of ca. $21 \mathrm{~kg}$ to a target weight of $43 \mathrm{~kg}$. Fat colour and firmness were evaluated subjectively on a 5-point scale. Samples of the subcutaneous fat and feed were collected for fatty acid and lutein analyses. Loin samples (L1-L6) were oven-roasted and fat characteristics evaluated by a trained sensory panel. The concentrations of lutein pigments and total long-chain fatty acids were influenced mainly by the fattening period $(p<0.05)$ and pelleting of the diets $(p<0.05)$. Lutein concentrations increased during longer fattening periods and resulted in lower colour scores for subcutaneous fat. Neither breed nor the maize content of the diet significantly affected the concentration of lutein in the subcutaneous fat. Lutein concentrations resulted in lower subjective colour scores $(p<0.05)$ and improved the aroma of lamb during carving $(p<0.05)$. The present results suggest that the 'unacceptable' lutein pigments contribute to the typical aroma of lamb.
\end{abstract}

Die doel van die studie was om die invloed van hoë mielie-diëte en verpilling van hoë mielie-diëte op die aansameling van luteinpigmente en voorkoms van die subkutanevet van Dorper en SA Vleismerino hamels te bestudeer. Hoë en medium energie mielie-diëte is aan Dorper en SA Vleismerino hamels vanaf ca. $21 \mathrm{~kg}$ tot teikenmassas van 37 en $43 \mathrm{~kg}$ gevoer. Onderhuidse vetmonsters en voermonsters is versamel vir vetsuur- en luteinontledings. Subkutanevet-eienskappe is subjektief geëvalueer op 'n 5-punt skaal. Monsters van die linker lende (L1- L6) is geoondbraai en vet-eienskappe is sintuiglik geëvalueer deur ' $n$ opgeleide proepaneel. Die konsentrasies van lutein pigmente en totale langketting-vetsure is beïnvloed deur die tydperk van vetmesting $(p<0.05)$ en die verpilling van die dieet $(p<0.05)$. Luteinkonsentrasies het verhoog tydens langer vetmestingsperiodes terwyl die kleur van die subkutane vet verswak het. Die ras en vlak van mieliemeel-insluiting in die dieet het geen betekenisvolle invloed gehad op die konsentrasies van lutein in die subkutane vet nie. Die konsentrasie van luteinpigmente het die subjektiewe kleurtellings verlaag $(p<0.05)$ en aroma tydens voorsny verbeter $(p<0.05)$. Die huidige resultate dui daarop dat ' $n$ klein hoeveelheid van die 'onaanvaarbare' luteinpigmente bydra tot die tipiese aroma van lamsvleis.

Keywords: Lutein pigments, diet, pelleting, fatty acids, fat, meat quality, sheep

* Author to whom correspondence should be addressed. E-mail: ecwebb@scientia.up.ac.za 


\section{Introduction}

As early as the 1960s a general consumer resistance towards carcasses with non-icteric yellow fat was noted (Hill, 1962a\&b). Consumer resistance was based on the perceptions that yellow fat is indicative of old age, or that the yellowed colour occasionally resulted from disease or that in beef fat, it is indicative of dairy type carcasses. In New Zealand it was noticed that between 3.5 and $7 \%$ of all sheep slaughtered contained yellow fat, but on a national basis it was not a major problem (Kirton et al., 1975). By contrast, Hill (1962b) reported high rejection rates of Irish carcasses owing to yellow coloration, and concluded that this problem is due to a simple recessive character inheritance. Kirton et al. (1975) suggested that the problem is more complicated since fat samples from all sheep and lamb carcasses contain at least a low level of the 'offending' pigment. In addition, the yellow carcasses were not diseased (i.e. not owing to jaundice) and were passed as fit for human consumption. Consequently Kirton et al. (1975) suggested that (i) markedly different dietary habits i.e. selection of highly pigmented plants, or (ii) differences in pastures between farms, or (iii) some metabolic defect which prevents the oxidation of the pigments, could be causative factors. Webb et al. (1997) reported a higher incidence of poor fat quality in early maturing wethers fed high-maize diets in the loose form and suggested that pelleting could improve fat consistency and colour. This paper reports on the influence of high-maize diets, dietary pelleting and breed on the accumulation of lutein pigments and appearance of the subcutaneous fat of sheep, and the related effects on meat quality.

\section{Materials and methods}

\section{Experimental design}

Shorn wethers were randomly allocated to a $2^{3}$ factorially arranged experiment ( 2 diets $\times 2$ dietary pelleting $\times 2$ breeds $\times 6$ replicates). Two diets were compiled on an isonitrogenous and isomineral basis to contain a medium (10,2 MJ metabolisable energy per kilogram dry material $(\mathrm{M})$ ) and high (11,8 MJ metabolisable energy per kilogram dry material $(\mathrm{H})$ ) level of maize meal as discussed by Webb et al. (1994a). These diets were presented in either the pelleted or loose form. The diets were fed ad libitum to Dorper (medium maturity breed) and SA Mutton Merino wethers (SAMM; late maturity breed) from initial live weights of $c a .21 \mathrm{~kg}$ to a target slaughter weight of $43 \mathrm{~kg}$. The carcasses were electrically stimulated $(21 \mathrm{~V}, 60 \mathrm{~Hz}, 120 \mathrm{~s})$ and chilled overnight $\left(4^{\circ} \mathrm{C}\right)$. Subcutaneous fat thicknesses (measured over the 13th rib, $25 \mathrm{~mm}$ from the medial plane), cold carcass weights and dressing percentages were recorded. Carcass measurements included, hindlimb width, forelimb width, carcass compactness and hindleg compactness (Webb, 1994).

\section{Sample collection}

Approximately $5-\mathrm{g}$ samples of subcutaneous fat were collected from the left side of each carcass at a point over the 13 th rib, $25 \mathrm{~mm}$ from the mid-line and stored in sealed polyethylene bags at $-20^{\circ} \mathrm{C}$ for fatty acid analysis (Webb et al., 1994a). Samples of the different diets presented in either the pelleted or loose form were collected weekly and kept in sealed polyethylene bags at $-20^{\circ} \mathrm{C}$ for subsequent fatty acid analysis. A three-rib sample (ribs 8-9-10) was cut from the left side of each carcass, the ventral extremity of the sample being on a line drawn from the pubic symphysis to the middle of the first rib (Casey et al., 1988). Three-rib samples were dissected into anatomical components in order to obtain an estimate of total carcass composition.

\section{Fatty acid analysis}

Lipids were extracted in duplicate by means of a modification (Ways \& Hanahan, 1964) of the 
chloroform:methanol $(2: 1, \mathrm{v} / \mathrm{v})$ method (Folch et al., 1957). Butylated hydroxytoluene $(2,6 \mathrm{DI}$-tertBUTYL-P-CRESOL) was included as antioxidant (Webb \& Casey, 1995a). Methyl esters of the fatty acid component of the neutral triglycerides were prepared according to the $\mathrm{NaOH} / \mathrm{methanol}$ method (AOAC, 1975). These esters were separated on a polar phase $S P 2330$ column $(2 \mathrm{~m} \times 3 \mathrm{~mm}$, packed with Silar 10C coated on Gas Chrom Q) fitted to a Varian 3700 gas chromatograph with a flame ionization detector. Standards for the fatty acids were obtained from Nu-Chek-Prep.Inc., Elysim, Minnesota (USA).

\section{Carcass fat quality}

The colour and firmness of carcass fat of wethers were evaluated subjectively on a 5-point scale of which the lower end (1) indicated the lowest assessment (yellow, soft fat) and the upper end (5) the highest (white, firm fat). Fat pigments were extracted according to the method of Kirton et al. (1975). No attempt was made to separate the carotenes and xanthophylls because the concentration of carotenes in ovine fat was shown to be almost negligible (Hill, 1962a\&b; Karijord, 1978; Singh \& Cramer, 1975; Kruggel et al., 1982). The absorbency of each fraction was measured on a spectrophotometer (Bausch \& Lomb Spectronic 21) at $441 \mathrm{~nm}$ and lutein concentrations calculated by employing Beer's Law equation (Kruggel et al., 1982).

\section{Fat quality evaluation}

A sample of the left loin (lumbar vertebrae L1-L6 with $\mathrm{m}$. longissimus dorsi) was collected from each carcass, vacuum packed and stored $\left(-20^{\circ} \mathrm{C}\right)$ for evaluation. After thawing, each loin sample (unsalted) was roasted on a rack in a preheated oven $\left(160^{\circ} \mathrm{C}\right)$ to an internal endpoint temperature of $70^{\circ} \mathrm{C}$ as previously described by Bosman et al. (1993). Fat quality characteristics of loin samples were evaluated immediately following cooking. The following classification factors were used namely aroma during cutting, firmness of the subcutaneous fat and fat to bone ratio (Webb, 1994). Sensory characteristics of the meat are discussed elsewhere (Bosman et al., 1994; Webb et al., 1994b).

\section{Statistical analysis}

Differences in fatty acid composition, carcass composition and fat quality characteristics between and within diets and breeds, as well as their interactions (diet $\times$ dietary pelleting $\times$ breed) were analysed by three-way analysis of variance and detected by Duncan's multiple range test using the General Linear Models (GLM) procedure of SAS (1992). The relationships among variables were analysed by means of Pearson product-moment correlations. Fat quality characteristics were crosstabulated in order to show frequency counts and differences were analysed by means of $\chi^{2}$-tests.

\section{Results and discussion}

\section{Experimental diets}

The lutein content of the medium and high-energy maize diets presented in either the loose or pelleted form did not differ significantly. Fatty acid profiles of the experimental diets were also similar and are discussed elsewhere (Webb \& Casey, 1995b).

\section{Growth and carcass results}

Growth and carcass results are summarised in Table 1. Dorper and SAMM wethers required on average $74.5 \pm 17.9$ days to reach the target weight of $43 \mathrm{~kg}$ and gained $241.8 \pm 70.2 \mathrm{~g}$ per day. The 
Table 1 Growth and carcass results (average SD) of Dorper and SA Mutton Merino wethers fed the $\mathrm{H}$-diet or $\mathrm{M}$-diet and presented in a pelleted or loose form: fattening period (FP3, average daily gain (ADG), subcutaneous fat thickness as measured over the 13th rib (SCF13), percentages of bone, muscle and fat, cold carcass weight (CCW) and dressing percentage $(D \%)$, hindlimb width (CWB), forelimb width (CWS), carcass compactness $(\mathrm{CCW} / \mathrm{K} 2 ; \mathrm{kg} / \mathrm{cm})$ and hindleg compactness (CCW/B $1 ; \mathrm{kg} / \mathrm{cm}$ )

\begin{tabular}{|c|c|c|c|c|c|c|}
\hline & \multicolumn{2}{|c|}{ Dietary treatment } & \multicolumn{2}{|c|}{ Breed } & \multicolumn{2}{|c|}{ Dietary presentation } \\
\hline & $\begin{array}{l}\text { H-diet } \\
(n=28)\end{array}$ & $\begin{array}{l}\text { M-diet } \\
(n=28)\end{array}$ & $\begin{array}{l}\text { Dorper } \\
(n=28)\end{array}$ & $\begin{array}{l}\text { SAMM } \\
(n=28)\end{array}$ & $\begin{array}{l}\text { Loose } \\
(n=28)\end{array}$ & $\begin{array}{l}\text { Pelleted } \\
(n=28)\end{array}$ \\
\hline$\overline{F P}$ (days) & $68.7 \pm 14.6^{\mathrm{a}}{ }_{\mathrm{A}}$ & $80.8 \pm 19.3^{b}{ }_{B}$ & $74.3 \pm 22.5$ & $74.7 \pm 12.4$ & $86.0 \pm 15.2^{c}{ }_{C}$ & $66.3 \pm 15.2^{\mathrm{d}}$ \\
\hline $\operatorname{ADG}(g)$ & $256.36 \pm 69.6 \mathrm{l}_{\mathrm{A}}^{\mathrm{a}}$ & $226.23 \pm 68.67^{b}{ }_{B}$ & $228.50 \pm 66.59$ & $255.12 \pm 72.35$ & $203.46 \pm 30.98^{\mathrm{c}} \mathrm{C}$ & $283.00 \pm 60.17^{d}$ \\
\hline $\mathrm{CCW}(\mathrm{kg})$ & $21.14 \pm 1.22$ & $20.59 \pm 1.35$ & $20.59 \pm 1.29$ & $21.17 \pm 1.27$ & $20.53 \pm 1.04$ & $21.12 \pm 1.42$ \\
\hline $\mathrm{D} \%$ & $49.54 \pm 2.07$ & $48.27 \pm 2.50$ & $48.96 \pm 2.35$ & $48.89 \pm 2.35$ & $48.92 \pm 2.39$ & $48.92 \pm 2.32$ \\
\hline $\mathrm{SCF} 13(\mathrm{~mm})$ & $4.18 \pm 1.74$ & $4.19 \pm 0.22$ & $4.66 \pm 2.13 a$ & $3.70 \pm 1.72 b$ & $4.14 \pm 2.47$ & $4.21 \pm 1.59$ \\
\hline Bone \% & $19.43 \pm 2.59$ & $20.27 \pm 2.73$ & $20.05 \pm 2.73$ & $19.62 \pm 2.64$ & $19.14 \pm 2.52$ & $20.32 \pm 2.70$ \\
\hline Muscle $\%$ & $48.98 \pm 4.49$ & $48.81 \pm 5.14$ & $47.44 \pm 4.78^{\mathrm{a}}$ & $50.35 \pm 4.38^{b}$ & $49.18 \pm 4.28$ & $48.69 \pm 5.15$ \\
\hline Fat $\%$ & $31.59 \pm 4.92$ & $30.93 \pm 5.63$ & $32.51 \pm 5.58^{\mathrm{a}}$ & $30.03 \pm 4.64^{b}$ & $31.67 \pm 6.03$ & $30.99 \pm 4.67$ \\
\hline$C W B(\mathrm{~cm})$ & $27.9 \pm 2.1$ & $27.5 \pm 1.8$ & $27.0 \pm 1.8^{\mathrm{a}}{ }_{\mathrm{A}}$ & $28.4 \pm 2.0^{\mathrm{b}} \mathrm{B}$ & $28.6 \pm 1.5^{\mathrm{c}}$ & $27.2 \pm 2.1^{\mathrm{d}}$ \\
\hline $\mathrm{CWS}(\mathrm{cm})$ & $21.4 \pm 1.4$ & $20.8 \pm 0.7$ & $20.7 \pm 1.3^{\mathrm{a}}$ & $21.6 \pm 0.8^{b}$ & $21.4 \pm 1.4$ & $20.9 \pm 0.9$ \\
\hline $\mathrm{CCW} / \mathrm{K} 2$ & $0.159 \pm 0.01$ & $0.156 \pm 0.01$ & $0.156 \pm 0.01$ & $0.159 \pm 0.01$ & $0.157 \pm 0.01$ & $0.157 \pm 0.01$ \\
\hline $\mathrm{CCW} / \mathrm{BI}$ & $0.436 \pm 0.04^{\mathrm{a}} \mathrm{A}$ & $0.405 \pm 0.03^{b}{ }_{B}$ & $0.410 \pm 0.03$ & $0.431 \pm 0.05$ & $0.416 \pm 0.05$ & $0.424 \pm 0.03$ \\
\hline
\end{tabular}

a.b.c\&d Means within the same row and column bearing different superscripts differ $(p<0.05)$. A B C\&D Means within the same row and column bearing different subscripts differ. (Carcass fat \% included as covariate; $p<0.05$ ).

average dressing percentage was $48.9 \pm 2.3 \%$, which yielded cold carcasses of $20.9 \pm 1.3 \mathrm{~kg}$. The average subcutaneous fat thickness was $4.1 \pm 2.0 \mathrm{~mm}$ and the percentages of bone, muscle and fat were respectively $19.8 \pm 2.7 \%, 48.9 \pm 4.7 \%$ and $31.2 \pm 5.2 \%$.

Fattening periods and average daily gains of wethers were influenced by the energy content of the diet $(p<0.05)$ and the presentation of the diet $(p<0.05)$. The average fattening period of wethers fed the H-diet was markedly shorter $(p<0.05)$ compared to that of wethers fed the M-diet, mainly because of the higher average daily gains $(p<0.05)$ achieved by wethers fed the H-diet $(p<0.05)$. Similarly, wethers fed pelleted diets had shorter fattening periods $(p<0.05)$ with greater average daily gains $(p<0.05)$ as opposed to those fed diets in the loose form. This was particularly true for the Dorper breed that tended to be more selective when fed diets in the loose form. Wethers fed pelleted diets could not select specific feed components. Consequently, Dorper wethers fed the highmaize diets in the pelleted form achieved similar feed intakes and growth rates when compared to the less selective SAMM wethers. The differences between breeds and between dietary presentations for both the fattening period and average daily gains remained significant $(p<0.05)$ regardless of the inclusion of carcass fatness as covariant to correct for differences in physiological maturity. Feed intake did not differ between breeds, but differences were observed between dietary treatments and between dietary presentations. Greater intakes $(p<0.05)$ and better feed conversion ratios $(p<0.05)$ were observed for wethers fed diets in the pelleted rather than the loose form.

Subcutaneous fat thickness measurements differed significantly between breeds $(p<0.05)$, which agrees with previous results (Bosman et al., 1993; Webb et al., 1994b). The average subcutaneous 
fat thickness obtained for the earlier maturing Dorper wethers $(4.6 \pm 2.6 \mathrm{~mm})$ was greater $(p<0.05)$ compared to the later maturing SAMM wethers $(2.4 \pm 1.0 \mathrm{~mm})$. However, these breed differences were eliminated almost entirely after the inclusion of carcass fatness as covariant. The results suggest that neither breed, treatment nor dietary pelleting significantly affect the thickness of the subcutaneous fat when wethers are compared at the same degree of maturity.

Although neither dietary treatment nor dietary pelleting influenced carcass composition, differences were observed in the proportions of muscle $(p<0.05)$ and fat $(p<0.05)$ between breeds. The earlier maturing breed generally contained more fat and less muscle in comparison with the later maturing breed. These differences were not significant after correcting for fatness.

Hindlimb widths of SAMM carcasses were greater $(p<0.05)$ in comparison with those of Dorper carcasses. Forelimb widths also differed between breeds $(p<0.05)$, but these differences were not significant when carcass fatness was included as covariant. Hindleg compactness differed between dietary treatments $(p<0.05)$, regardless of dietary pelleting. Wethers fed the H-diet yielded carcasses with higher hindleg compactness measurements as opposed to those fed the M-diet $(p<0.05)$, and the differences remained significant regardless of the inclusion of carcass fatness as covariant. Neither diet, dietary pelleting nor breed significantly influenced carcass compactness measurements.

\section{Molar proportion (molar \%) fatty acid methyl esters in subcutaneous fat}

The composition of fatty acids in the subcutaneous fat of Dorper and SAMM wethers fed the H-diet and M-diet and presented in either the loose or pelleted form are presented in Table 2. Molar proportions of fatty acids were influenced mainly by dietary energy levels $(p<0.05)$, while the effect of

Table 2 Composition of fatty acids in subcutaneous fat of Dorper and SA Mutton Merino wethers fed the $\mathrm{H}$-diet or $\mathrm{M}$-diet and presented in either the loose $(\mathrm{L})$ or pelleted $(\mathrm{P})$ form (expressed either as a molar proportion of total long chain fatty acids or gravimetric concentrations)

\begin{tabular}{|c|c|c|c|c|c|c|c|c|}
\hline \multirow{3}{*}{$\begin{array}{l}\text { Fatty } \\
\text { acids }\end{array}$} & \multicolumn{4}{|c|}{ H-diet } & \multicolumn{4}{|c|}{ M-diet } \\
\hline & \multicolumn{2}{|c|}{ Dorper } & \multicolumn{2}{|c|}{ Samm } & \multicolumn{2}{|c|}{ Dorper } & \multicolumn{2}{|c|}{ Samm } \\
\hline & $L(n=6)$ & $P(n=6)$ & $L(n=6)$ & $P(n=6)$ & $L(=6)$ & $P(n=6)$ & $L(n=6)$ & $P(n=6)$ \\
\hline \multicolumn{9}{|c|}{ Molar \% } \\
\hline $\mathrm{Cl} 18: 0$ & $20.1 \pm 2.8^{2}$ & $11.1 \pm 2.0^{b}$ & $20.9 \pm 3.6^{\mathrm{c}}$ & $15.7 \pm 2.5^{d}$ & $23.1 \pm 2.7^{c}$ & $17.7 \pm 4.2^{\mathrm{f}}$ & $23.6 \pm 2.9^{\mathrm{g}}$ & $22.4 \pm 2.2^{h}$ \\
\hline C18:1 & $41.1 \pm 3.2^{\mathrm{a}}$ & $45.0 \pm 2.2^{b}$ & $38.3 \pm 1.9^{\mathfrak{a}}$ & $43.7 \pm 2.9^{b}$ & $37.5 \pm 2.4^{\mathrm{c}}$ & $40.3 \pm 4.3^{d}$ & $35.1 \pm 2.7^{\mathrm{c}}$ & $38.2 \pm 1.6^{d}$ \\
\hline SFA\% & $49.6 \pm 2.5^{2}$ & $41.7 \pm 3.4^{b}$ & $50.1 \pm 3.9^{a}$ & $44.7 \pm 4.7^{b}$ & $52.2 \pm 2.7^{\mathrm{c}}$ & $45.4 \pm 2.2^{d}$ & $54.6 \pm 2.3^{c}$ & $52.4 \pm 3.1^{d}$ \\
\hline MUFA $\%$ & $44.6 \pm 3.4^{a}$ & $49.9 \pm 3.3^{b}$ & $41.9 \pm 2.3^{c}$ & $46.9 \pm 4.5^{d}$ & $40.5 \pm 2.8^{\mathrm{e}}$ & $43.8 \pm 2.5^{f}$ & $37.9 \pm 2.8^{\mathrm{s}}$ & $40.2 \pm 2.4^{h}$ \\
\hline PUFA\% & $4.3 \pm 0.7^{a}$ & $5.1 \pm 1.5^{b}$ & $4.7 \pm 1.1^{\mathrm{a}}$ & $6.1 \pm 1.5^{b}$ & $5.1 \pm 1.1^{c}$ & $7.6 \pm 1.8^{\mathrm{d}}$ & $5.9 \pm 0.9^{c}$ & $6.1 \pm 1.1^{\mathrm{d}}$ \\
\hline \multicolumn{9}{|c|}{ Fat (mg/g) } \\
\hline [SFA] & $117.4 \pm 29^{a}$ & $61.2 \pm 26.1^{b}$ & $167.8 \pm 67^{c}$ & $92.5 \pm 39.7^{d}$ & $107.1 \pm 29^{a}$ & $67.6 \pm 31.1^{b}$ & $147.4 \pm 45.2^{\mathrm{c}}$ & $93.3 \pm 40.6^{d}$ \\
\hline [UFA] & $106.8 \pm 25^{2}$ & $83.2 \pm 38.7^{b}$ & $142.3 \pm 56^{\mathrm{a}}$ & $104.3 \pm 40.1^{b}$ & $87.0 \pm 22^{\mathrm{z}}$ & $77.2 \pm 31.8^{b}$ & $115.6 \pm 42.3^{\mathrm{a}}$ & $80.8 \pm 43.6^{b}$ \\
\hline [MUFA] & $.84 .2 \pm 23^{a}$ & $63.7 \pm 28.8^{b}$ & $107.5 \pm 20^{\mathrm{a}}$ & $73.5 \pm 27.1^{b}$ & $63.9 \pm 19.6^{c}$ & $49.8 \pm 21.6^{d}$ & $78.3 \pm 28.0^{\mathrm{c}}$ & $55.7 \pm 31.2^{d}$ \\
\hline [PUFA] & $23.3 \pm 3.9^{\mathrm{a}}$ & $19.5 \pm 10.9^{\mathrm{a}}$ & $35.9 \pm 18.2^{b}$ & $30.8 \pm 15.4^{b}$ & $23.7 \pm 4.5^{\mathrm{s}}$ & $27.4 \pm 10.9^{\mathrm{a}}$ & $37.3 \pm 14.4^{b}$ & $25.1 \pm 12.7^{b}$ \\
\hline$[\mathrm{FA}]_{\text {Total }}$ & $225.0 \pm 53^{\mathrm{a}}$ & $144.5 \pm 63.8^{b}$ & $311.3 \pm 122^{\mathrm{c}}$ & $196.9 \pm 78.3^{d}$ & $194.8 \pm 50^{2}$ & $144.7 \pm 62.8^{b}$ & $263.0 \pm 86.0^{\mathrm{c}}$ & $174.1 \pm 82.8^{d}$ \\
\hline
\end{tabular}


breed and dietary pelleting were less apparent and agrees with previous results (Webb et al., 1994). The proportion of stearic acid (C18:0) was significantly higher in the later maturing breed $(p<0.05)$, particularly in the group receiving pelleted diets. A greater proportion of oleic acid (C18:1;p<0.05) was observed in the earlier maturing breed.

A greater proportion of unsaturated fatty acids was deposited in the fat of wethers fed pelleted diets as opposed to diets in the loose form $(p<0.05$ ). A concomitant improvement in fat quality (particularly fat firmness) was observed for wethers fed pelleted diets. By contrast, increasing proportions of unsaturated fatty acids are generally associated with a decline in fat firmness. The improvement observed in fat quality is presumably related to the significantly shorter fattening periods of wethers fed pelleted diets, which resulted in the accumulation of smaller gravimetric concentrations of total fatty acids, notably saturated and unsaturated fatty acids. It appears that the balance between the proportions of saturated and unsaturated fatty acids becomes increasingly important as greater concentrations of total fatty acids are deposited i.e. during fattening.

\section{Gravimetric concentration of fatty acids in subcutaneous fat ( $\mathrm{mg} / \mathrm{g}$ of adipose tissue)}

Smaller concentrations of total fatty acids $(p<0.01)$ were detected in the subcutaneous fat of wethers fed pelleted diets as opposed to those fed diets presented in the loose form (Table 2). It appears that greater concentrations of fatty acids accumulate in the subcutaneous fat during longer fattening periods. Greater concentrations of saturated $(p<0.01)$ and poly-unsaturated $(p<0.01)$, but not mono-unsaturated fatty acids, accumulated in the fat of the earlier maturing breed compared to the later maturing breed. By contrast a significantly greater concentration of mono-unsaturated fatty acids $(p<0.01)$ was deposited in the fat of wethers fed the H-diet as opposed to the M-diet. In a previous publication it was also suggested that dietary energy levels influence mainly the proportions of fatty acids deposited or synthesised, while the degree of maturity (breed), presentation of the diet and fattening period affect the concentrations of fatty acids (Casey \& Webb, 1995).

\section{Colour and firmness of carcass fat}

The average (pooled) subjective scores for fat colour and fat firmness of wether carcasses were respectively $3.1 \pm 0.9$ and $2.3 \pm 1.2$. Although the subcutaneous fat tended to be slightly yellow, fat firmness scores were generally acceptable i.e. scores $>3$. Both the firmness and colour of carcass fat were influenced by breed $(p<0.01)$ and diet $(p<0.01)$ as indicated in Table 3. Carcasses of the earlier maturing breed contained softer fat $(p<0.01)$ with a poorer colour $(p<0.01)$ as opposed to SAMM wethers. Wethers fed the H-diet also tended to yield carcasses with a softer fat $(p<0.01)$ and

Table 3 Scores for fat colour (CCF), firmness (FCF) of subcutaneous fat and lutein concentrations $(\mathrm{mg} / 100 \mathrm{~g})$ in the diets and subcutaneous fat from Dorper (D) and SA Mutton Merino wethers (SAMM) fed the $\mathrm{H}$-diet or $\mathrm{M}$-diet and presented in either the loose $(L)$ or pelleted $(P)$ form

\begin{tabular}{|c|c|c|c|c|c|c|c|c|}
\hline & \multicolumn{4}{|c|}{ H-diet (ca. $1.57 \mathrm{mg}$ lutein $/ 100 \mathrm{~g}$ feed) } & \multicolumn{4}{|c|}{ M-diet (ca. $1.75 \mathrm{mg}$ lutein / $100 \mathrm{~g}$ feed) } \\
\hline & \multicolumn{2}{|c|}{ Dorper } & \multicolumn{2}{|c|}{ SAMM } & \multicolumn{2}{|c|}{ Dorper } & \multicolumn{2}{|c|}{ SAMM } \\
\hline & $L(n=6)$ & $\mathrm{P}(n=6)$ & $L(n=6)$ & $\mathrm{P}(n=6)$ & $L(n=6)$ & $\mathrm{P}(n=6)$ & $\mathrm{L}(n=6)$ & $\mathrm{P}(n=6)$ \\
\hline$\overline{\mathrm{FCF}}$ & $1.7 \pm 1.0^{\mathbf{a}}$ & $2.8 \pm 0.7^{b}$ & $3.7 \pm 0.5^{\mathrm{c}}$ & $3.3 \pm 0.8^{c}$ & $2.8 \pm 0.9^{b}$ & $2.8 \pm 0.4^{b}$ & $3.8 \pm 0.4^{d}$ & $3.8 \pm 0.4^{\mathrm{d}}$ \\
\hline $\mathrm{CCF}$ & $0.8 \pm 0.7^{\mathrm{a}}$ & $2.0 \pm 1.1^{b}$ & $3.0 \pm 0.6^{\mathrm{c}}$ & $2.7 \pm 1.0^{\mathrm{c}}$ & $1.8 \pm 0.9^{\dot{d}}$ & $1.8 \pm 0.4^{d}$ & $3.3 \pm 0.8^{e}$ & $3.5 \pm 0.8^{\mathrm{e}}$ \\
\hline [Lutein] & $1.26 \pm 0.20^{\mathrm{a}}$ & $0.82 \pm 0.24^{b}$ & $1.07 \pm 0.28^{\mathrm{a}}$ & $0.68 \pm 0.24^{b}$ & $1.04 \pm 0.22 \mathrm{a}$ & $0.97 \pm 0.65^{b}$ & $1.02 \pm 0.16^{\mathrm{a}}$ & $0.82 \pm 0.30^{\mathrm{b}}$ \\
\hline
\end{tabular}


less acceptable colour $(p<0.01)$. Lowest scores for fat firmness and colour were obtained for Dorper wethers fed diets in the loose form. Both the firmness and colour of carcass fat from Dorper wethers fed high-maize diets in the pelleted form scored significantly higher $(p<0.01)$ compared to those presented in the loose form. Dietary pelleting did not significantly affect carcass fat quality of SA Mutton Merino wethers i.e. fat firmness and colour scores obtained for SA Mutton Merino carcasses were acceptable regardless of treatment. Differences in the firmness of the fat between dietary energy levels disappeared when carcass fat percentage was included as covariant, but those between breeds remained significant $(p<0.01)$. Fat colour of Dorper carcasses $(1.6 \pm 0.9)$ also remained less acceptable in comparison with that of SA Mutton Merinos $(3.0 \pm 0.9 ; p<0.01)$.

\section{Fat quality of roasted loin samples}

Summary statistics and log-linear analysis ( $\chi^{2}$-tests) of fat quality characteristics of roasted loin samples are provided in Table 4. Frequency counts obtained for the aroma during cutting of roasted loin samples suggest no significant differences between diets, breeds or dietary presentations. The incidence of a strange aroma during cutting was negligible. However, the firmness of the subcutaneous fat covering the loin samples was influenced primarily by breed $(p<0.01)$ and dietary pelleting $(p<0.01)$. The incidence of soft fat was higher in the earlier maturing Dorper breed $(p<0.01)$, particularly when fed high-maize diets in the loose form. The presentation of high-maize diets in the pelleted form to Dorpers resulted in a significant reduction in the frequency of soft fat $(p<0.01)$. Similarly, the incidence of soft fat in SAMM wethers was reduced when fed high-maize diets in the pelleted form $(p<0.01)$. Differences in the ratio of fat to bone in roasted loin samples were observed mainly between breeds $(p<0.01)$. Roasted loin samples from Dorpers tended to contain abundant amounts of fat $(p<0.01)$, while the observed frequency was significantly smaller for SAMM wethers. Although the pelleting of high-maize diets generally tended to improve the fat to bone

Table 4 Observed frequencies and log-linear analysis ( $\chi^{2}$-test) of fat characteristics [aroma (AML); firmness of the fat (FML) and fat-to-bone ratios (F:B)] of loin samples from Dorper (D) and SA Mutton Merino wethers (SAMM) fed different dietary energy levels presented in the loose $(L)$ and pelleted $(P)$ form

\begin{tabular}{|c|c|c|c|c|c|c|c|c|c|}
\hline & & \multicolumn{4}{|c|}{ H-diet $(n=24)$} & \multicolumn{4}{|c|}{ M-diet $(n=243$} \\
\hline & & \multicolumn{2}{|c|}{$\mathrm{D}(n=12)$} & \multicolumn{2}{|c|}{$\operatorname{SAMM}(n=12)$} & \multicolumn{2}{|c|}{$\mathrm{D}(n=12)$} & \multicolumn{2}{|c|}{$\operatorname{SAMM}(n=12)$} \\
\hline & & $\mathrm{L}(n=6)$ & $\mathrm{P}(n=6)$ & $\mathrm{L}(n=6)$ & $\mathrm{P}(n=6)$ & $L(n=6)$ & $\mathrm{P}(n=6)$ & $\mathrm{L}(n=6)$ & $\mathrm{P}(n=6)$ \\
\hline \multirow[t]{2}{*}{$\overline{\text { AML }}$} & Typical & 12.5 & 12.5 & 12.5 & 12.5 & 12.5 & 12.51 & 10.42 & 12.5 \\
\hline & Strange & 0 & 0 & 0 & 0 & 0 & 0 & 2.08 & 0 \\
\hline \multirow[t]{4}{*}{ FML } & Firm & 2.08 & 12.5 & 10.42 & 12.5 & 2.08 & 12.5 & 12.5 & 12.5 \\
\hline & Slightly soft & 0 & 0 & 0 & 0 & 0 & 0 & 0 & 0 \\
\hline & Soft & 10.42 & 0 & 2.08 & 0 & 10.42 & 0 & 0 & 0 \\
\hline & & a & b & $\mathrm{c}$ & b & a & b & b & $\mathrm{b}$ \\
\hline \multirow[t]{3}{*}{$\mathbf{F}: \mathbf{B}$} & Little & 0 & 8.34 & 10.42 & 6.25 & 0 & 4.16 & 10.42 & 10.42 \\
\hline & Medium & 0 & 0 & 0 & 0 & 0 & 0 & 0 & 0 \\
\hline & Abundant & 12.5 & 4.17 & 2.08 & 6.25 & 12.5 & 8.33 & 2.08 & 2.08 \\
\hline
\end{tabular}

${ }^{2 . b \& c}$ Groups of frequencies within the same row bearing different superscripts differ $(p<0.01)$. 
ratios, the difference between dietary presentations was not statistically significant.

\section{Subcutaneous fat pigments and fat quality}

The results of the present study suggest that slightly higher concentrations of lutein occurred in the fat of Dorpers compared to SA Mutton Merinos (Table 4), but only dietary pelleting significantly affected $(p<0.01)$ the lutein content of lamb fat. Kruggel et al. (1982) reported higher levels of lutein in the fat from lambs fed a low energy alfalfa diet as opposed to a high grain diet. These differences were evidently due to the significantly higher lutein content of the low energy alfalfa diet. By contrast, the lutein content of the $\mathrm{H}$ - and $\mathrm{M}$-diets in the present study did not differ significantly. The effect of dietary pelleting on the lutein content seems to be related more to the fattening period, which presumably resulted in the greater accumulation of lutein in wethers fed diets in the loose rather than the pelleted form. A similar accumulation of total fatty acids (mg/g adipose tissue) were observed $(p<0.05)$. The results also suggest that greater concentrations of lutein may result in lower colour scores $\left(r_{x y}=-0.32 ; p<0.05\right)$, which agrees with the results of Kruggel et al. (1982) who concluded that lower levels of lutein may decrease the amount of yellow pigment in the fat, but the fat may still be objectionable from a firmness standpoint. The positive correlation between lutein and fat firmness obtained by Kruggel et al. (1982) and the negative correlation obtained in the present study suggest that the relationship between lutein and fat firmness is inconsistent so that fat from wethers containing higher levels of lutein is not necessarily soft.

Although Kruggel et al. (1982) questioned the cause-and-effect relationship $\left(r_{x y}=0.45\right)$ between lutein and flavour. In the present study a positive correlation $\left(r_{x y}=0.33 ; p<0.05\right)$ was obtained between lutein and aroma. A greater concentration of lutein was associated with the typical lamb aroma. Sink \& Caporaso (1977) also indicated that lambs fed legumes like alfalfa (which contains high levels of lutein) could intensify the flavour of cooked lamb. Contrary to previous reports (Hill, $1962 \mathrm{~b}$ ) the present results suggest that at least a low level of the 'offending' xanthophyll pigment contributes to the typical aroma of mutton.

\section{Conclusions}

High levels of maize in fattening diets influence mainly the proportions of fatty acids in the subcutaneous fat, while the form of the diet and fattening period affect the concentrations of fatty acids. Similarly, greater concentrations of lutein pigments accumulate in the subcutaneous fat over longer fattening periods, which may result in lower colour scores. Accumulation of lutein pigments in the subcutaneous fat correlated significantly with subjective colour scores, but were not significantly affected by the breed or energy content of the diet.

It appears to be possible to fatten wethers on high-maize diets without any detrimental effects on the quality of the subcutaneous fat, provided that they are fed pelleted diets for a limited period. When wethers are fattened for longer periods on high-maize diets, the accumulation of lutein and unsaturated fatty acids in the subcutaneous fat may result in yellow, soft carcass fat.

\section{Acknowledgments}

The authors acknowledge the technical assistance rendered by Mr E.B. Spreeth and Mrs E.M. Webb.

\section{References}

AOAC, 1975. Official methods of analysis of the Association of Official Analytical Chemists, pp.497. BOSMAN, M.J.C., WEBB, E.C., CASEY, N.H., VAN AARD, A.M., KRUGER, H.S. \& STEYN, H.S., 1993. 
Die invloed van verskillende energievlakke van die dieet op eet- en vetkwaliteit en gaarmaakverliese van lamsvleis van verskillende rasse. J. Diet. Home Econ. 21, 107.

BOSMAN, M.J.C., WEBB, E.C., CASEY, N.H., VAN AARD, A.M. \& SILVIS, N., 1994. Die invloed van hoë en medium energiediëte in die verpilde vorm op die eet- en vetkwaliteit asook gaarmaakverliese van lamsvleis van verskillende rasse. J. Diet. Home Econ. 22, 19.

CASEY, N.H., VAN NIEKERK, W.A. \& SPREETH, E.B., 1988. Fatty acid composition of subcutaneous and kidney fat of sheep grazed on eight different pastures. Meat Sci. 23, 55.

CASEY, N.H. \& WEBB, E.C., 1995. Influence of dietary energy levels and form of the diet on the composition of fatty acids in the subcutaneous adipose tissue of wethers. Small Rum. Res. 18, 125.

FOLCH, J., LEES, M. \& STANLEY, H.S., 1957. A simple method for the isolation and purification of total lipids from animal tissues. J. Biol. Chemistry 226, 497.

HILL, F., 1962a. Xanthophyll pigmentation in sheep fat. Nature 194, 865.

HILL, F, 1962b. Yellow fat in sheep. Irish J. Agric. Res. 1, 84.

KARIJORD, O., 1978. Correlation between the content of carotenoids in depot fat and plasma of sheep. Acta. Scand. 28, 355.

KIRTON, A.H., CRANE, B., PATTERSON, D.J. \& CLARE, N.T., 1975. Yellow fat in lambs caused by carotenoid pigmentation. New Zealand J. Agric. Res. 18, 267.

KRUGGEL, W.G., FIELD, R.A., MILLER, G.J., HORTON, K.M. \& BUSHBOOM, J.R., 1982. Influence of sex and diet on lutein in lamb fat. J. Anim. Sci. 54, 970.

SAS INSTITUTE INC., 1992. SAS user's guide: Statistics. SAS Institute Inc., Cary, N.C.

SINGH, H. \& CRAMER, H.R., 1975. Metabolism of carotenoids. J. Sci. Ind. 34, 219.

SINK, J.D. \& CAPORASO, F., 1977. Lamb and mutton flavor; contributing factors and chemical aspects. Meat Sci. 1, 119.

WAYS, P. \& HANAHAN, D.J., 1964. Characterization and quantification of red cell lipids in normal man. $J$. Lipid Res. 5, 318.

WEBB, E.C., 1994. Synthesis of long chain fatty acids in ruminants and their effects on meat quality. PhDthesis, University of Pretoria, Pretoria, South Africa.

WEBB, E.C., BOSMAN, M.J.C. \& CASEY, N.H., 1994b. Dietary influences on subcutaneous fatty acid profiles and sensory characteristics in Dorper and SA Mutton Merino wethers. SA Jnl. Food Sci. \& Nutr. 6 , 45.

WEBB, E.C., BOSMAN, M.J.C. \& CASEY, N.H., 1997. Influence of dietary presentation on the composition of fatty acids and sensory characteristics of meat from wethers. SA Jnl. Food Sci. \& Nutr. 9, 69.

WEBB, E.C. \& CASEY, N.H., 1995a. Fatty acids in the carcass fat of steers treated with a $\beta$-adrenergic agonist feed additive and a trenbolone acetate + oestradiol-17ß implant. Meat Sci. 41, 69.

WEBB, E.C. \& CASEY, N.H., 1995b. Genetic differences in the composition of fatty acids in the subcutaneous adipose tissue of Dorper and SA Mutton Merino wethers at different live weights. Small Rum. Res. $18,81$.

WEBB, E.C., CASEY, N.H. \& VAN NIEKERK, W.A., 1994a. Fatty acids in the subcutaneous adipose tissue of intensively fed SA Mutton Merino and Dorper wethers. Meat Sci. 38, 123. 